\title{
Prediction of existing gully erosion in vineyard parcels of the NE Spain: a logistic modelling approach
}

\author{
A. Meyer ${ }^{\mathrm{a}}$, J.A. Martínez-Casasnovas ${ }^{\mathrm{b}, *}$ \\ ${ }^{a}$ Institute of Physical Geography and Landscape Ecology, University of Hannover, Hannover, Germany \\ ${ }^{\mathrm{b}}$ Department of Environment and Soil Science, University of Lleida, Rovira Roure 177, 25198 Lleida, Spain
}

Received 25 August 1998; received in revised form 29 January 1999; accepted 24 February 1999

\begin{abstract}
This paper presents a study of determining factors and a method to predict the existence of gully erosion in vineyard parcels. The Alt Penedès-Anoia region (Catalonia, NE Spain), mainly dedicated to the cropping of vineyards for high quality wine production, was selected as the case study area. Single factors related to the existence of gully erosion were determined by means of statistical tests (Student's $t$-test and chi-square). The existence of gully erosion was predicted by means of a multivariate procedure. A stepwise selection of variables (relief, soil, land use/management characteristics) was performed, which allowed the identification of factors that present a significant relationship with the existence of gully erosion. The selected factors, slope degree and planar slope form, were considered as independent variables in a logistic regression of binary response. The model computes the probability that gullies exist in given vineyard parcels, and it can be implemented in a raster-based geographical information system (GIS). The assessment of the model in 52 parcels, different from the training data set, yielded an overall accuracy of $84.6 \%$. The predictive model can be applied for areas with similar conditions, but the modelling approach can be applied in other different areas. (C) 1999 Elsevier Science B.V. All rights reserved.
\end{abstract}

Keywords: Gully erosion; GIS; Logistic regression

\section{Introduction}

\subsection{Gully erosion: importance and modelling methods}

Gully erosion is a serious problem specifically in certain areas, because of climate, lithology, soils, relief characteristics, and land use. The Alt Penedès-Anoia (Catalonia, NE Spain), a region located in the Mediterranean basin, is a clear example.

\footnotetext{
*Corresponding author. Tel.: +34-973702615; fax: +34973702613; e-mail: j.martinez@macs.udl.es
}

Porta et al. (1994) and Martínez-Casasnovas (1998), using aerial photo-interpretation, gave respective rates of $20 \%$ and $31.9 \%$ of total area affected by large gullies in some areas of that region. That indicates the importance and implications of the erosion problem in these agricultural areas: reduction of parcel's size, soil losses, need of costly control practices, damage of infrastructures, etc. Other important implications are dissection of landscape and environmental pollution.

Several factors are responsible for the existence of serious gully erosion problems in some regions of the Mediterranean basin. On one hand, the lithology of parent materials (marls in many areas) and the semi- 
arid climate, with hot and dry summers that frequently coincide or are followed by high intensity rainfalls (Ramos and Porta, 1993, 1994; Hill, 1993; Uson, 1998). Also during the last centuries, human activities have substantially transformed natural mixed forested areas into agricultural land. The dominant crops (cereals, vineyards, olive and almond trees) only cover the soil during specific periods or with partial coverage, making soil unprotected against high intensity rainfalls. Moreover, due to the advent of mechanisation, parcels have been transformed to adapt them to modern machinery. This has involved elimination of traditional soil conservation measures, with a negative repercussion on soil erosion.

Gully erosion is usually a regional problem that has to be controlled from the parcel level to the regional level. Control at the regional level is difficult to achieve since the affected region usually does not have unique, clear authority, or because huge investments are required for a subject that is not considered a priority. Control at the parcel level is more feasible, but in most cases farmers do not see the necessity of implementing control measures. Ephemeral gullies that grow in parcels are routinely removed by conventional tillage or filled with soil materials. Gullies are usually found in natural drainage ways within the parcels (Laflen et al., 1986), where runoff is concentrated (Poesen, 1989; Poesen and Govers, 1990; Vandaele et al., 1996). In comparison with rill erosion, ephemeral gullies usually occur at the same place after each high intensity rainfall, and may lead to typical gullies.

Identification of areas at the parcel level with high probability of gully erosion constitutes a core element for conservation planning. This information will be useful for farmers as well as for regional planners to know location of risk areas and the level of the risk.

Gully erosion processes are less well understood than other erosion processes (Heede, 1979; Imeson and Kwaad, 1980; Zink, 1997). Most research has been addressed to analyse gully morphology and the stages of gully development as a first step in evaluating gully processes and assessing the potential for gully erosion (Ireland et al., 1939; Heede, 1970; Imeson and Kwaad, 1980; Crouch and Blong, 1989). Gully erosion modelling has focused more on development of qualitative and empiric-statistical models than in the formulation of physically based models (Thompson,
1964; Seginer, 1966; Williams and Morgan, 1976; Stocking, 1980; Donker and Damen, 1984). Most of them are multivariate regression equations based on factors which have a proven correlation with existing gully erosion. These equations either predict rates of advance of gully heads for established gullies or give threshold values, above which development of gullies can be expected.

The present paper is a contribution to both: (a) the analysis of terrain and land use/management factors determining the existence of gully erosion, particularly in the Alt Penedès-Anoia region, and (b) the prediction of existing gully erosion at the parcel level in vineyards. First, the correlation of existing gully erosion with single terrain and land use/management factors is determined by means of statistical analysis. Second, a method to predict the existence of gully erosion at the parcel level is presented. The last is assessed in terms of the probability to find gullies in a parcel as a function of related terrain and land use/ management variables. Probabilities are based on a logistic regression of binary response, for which a large number of variables have been evaluated according to a multivariate approach.

\subsection{The study area}

The Alt Penedès-Anoia region (Catalonia, NE Spain) is an agricultural area traditionally dedicated to production of high quality wines and "cavas" (sparkling wine produced by means of the Champagne method) (Fig. 1).

The area is located about $30-40 \mathrm{~km}$ south west of Barcelona between the Sierra Prelitoral mountains and the Anoia and Llobregat rivers. This area is part of the Penedès tertiary depression. It includes calcilutites (marls) with occasional sandstones and conglomerates. In the central part of the depression, these conglomerates are consolidated, however, the conglomerates in the northern part of the study area are unconsolidated and no residual landforms are found in this area.

The area lies within the temperate to maritime Mediterranean climate. Mean annual rainfall ranges from 471 to $670 \mathrm{~mm}$ (Porta et al., 1994). Its distribution is irregular, with high intensity rainstorms during autumn, after the dry season, with high erosive potential (Ramos and Porta, 1993). Soils are highly calcar- 


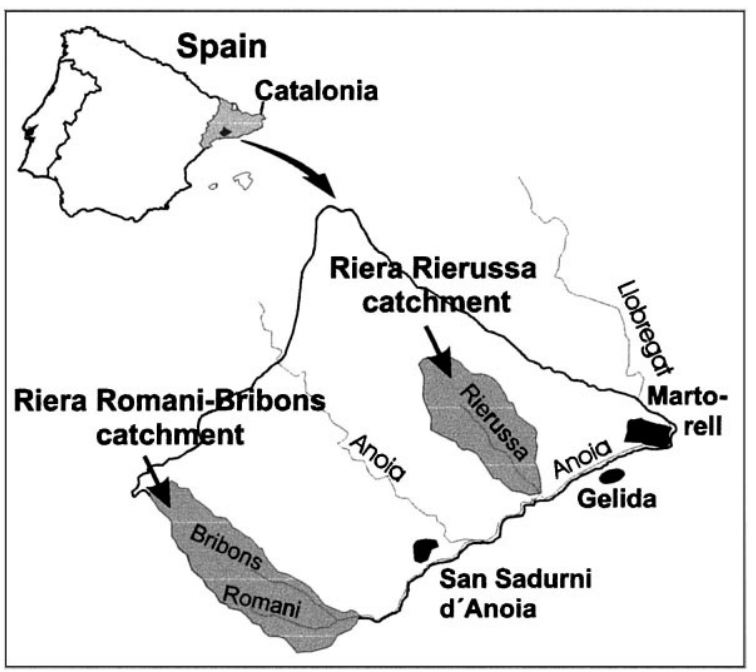

Fig. 1. Location of the study area.

eous. According to Soil Taxonomy (SSS, 1996) they are classified as Xerorthents typics, Xerochrepts calcixerollic, Xerochrepts petrocalcic and Xerochrepts fluventics. Other categories as Palexeralfs and Haploxeralfs have also been described and mapped in this area (Martínez-Casasnovas, 1998). These have been truncated by hydric erosion, and at present, are only relicts.

The main land use is vineyards (35\% of the area). Other important uses are winter cereals $(6 \%$ of the area) that alternate with vineyards. Natural vegetation and forest is confined at mountains, walls of large gullies, and abandoned agricultural parcels (very sloping areas of small parcels).

One of the main characteristics of the area is the dissection of the landscape by a dense and deep network of gullies. Inter-gully areas are usually undulating to rolling with complex slopes. Large gullies are characterised by vertical sidewalls and are 10 or more meters deep in many places. The development of the gully system has been favoured by the cropping of vineyards. This culture strongly generates overland flow during high intensity precipitation events. Surplus runoff is usually concentrated in hillside ditches (called "rases") that flow either into main drainage channels or directly into gullies. This favours formation of gullies at ditches or drainage outlet points and in this manner the gully network enlarges linearly. Gullies grow by deepening in the unconsolidated tertiary deposits. Mass movements on sidewalls produce parallel widening of gullies.

Within the parcels, ephemeral gullies are repetitively smoothed over by tillage, but the causes of these temporary appearances are not taken into account. Continuous erosion removes part of the nutrient-rich top soil and could rapidly lead to diminishing yields. Also other damages occur: dissection of parcels or difficulty for machinery traffic.

The agricultural system suffered a substantial transformation since the advent of mechanisation in the 1950s, which has lead to an ever increasing land degradation. Huge soil movements needed to achieve parcels with longer vine rows and lower slope degrees, soil compaction caused by heavy machinery, and the lack of appropriate conservation measures have led to reactivate erosion processes.

In the long run, one can say that the sustainability of present agricultural land uses and soils are threatened by erosion and operational techniques to identify priority areas to implement control measures which are urgently needed.

\section{Methods and materials}

The research was carried out in two sample catchments of the Alt Penedès-Anoia region. Those are the Rierussa and Romani-Bribons catchments with a size of about $25 \mathrm{~km}^{2}$ each (Fig. 1). They were selected because of differences in landscape characteristics (Table 1).

In those catchments, 40 vineyard parcels (20 with and 20 without evidence of gully erosion: ephemeral and small typical gullies $0.3-1 \mathrm{~m}$ deep and $0.5-1.5 \mathrm{~m}$ wide) were sampled. Those parcels were representative of the most frequent geoforms of the catchments as well as typical vineyard management practices (for example, orientation of the vine rows with respect to the maximum slope direction or the existence of levelling).

The elementary or basic spatial unit (b.s.u.) for data collection was the minimum support area required to drain to a point for water to flow in a concentrated manner and for a channel to form (Rieger, 1993). Its boundary may differ from the parcel one.

For each sampling unit, a set of 23 potential factors related to the development of gullies in vineyard 
Table 1

Main relief and lithologic characteristics of the sample catchments

Rierussa catchment

(high dissected valley-glacis landscape unit)

Romani-Bribons catchment

(low dissected valley-glacis landscape unit)
Relief: typically complex slopes, rolling to hilly terrain (5-20\% slope degree). Slopes are abruptly incided by deep gullies. Mean relieve amplitude 13-20 m (out of gullies). Drainge density $3.4 \mathrm{~km} \mathrm{~km}^{-2}$

Geoforms: rounded crests, gentle complex slopes (5-10\% slope degree), sloping complex slopes (10-15\% slope degree), moderate steepy slopes (15-25\% slope degree)

Lithology: tertiary marls, sandy marls and conglomerates (unconsolidated)

Relief: typically simple linear or concave slopes, gentle or moderate slope degree (1-10\%). Relieve amplitude: between $6 \mathrm{~m}$ in rounded crests and $19 \mathrm{~m}$ in moderate degree slopes. Drainage density $3.2 \mathrm{~km} \mathrm{~km}^{-2}$

Geoforms: rounded crests and sloping concave slopes (5-10\% slope degree), glacis and gentle slopes (1-5\% slope degree), moderate sloping to steepy slopes (5-20\% slope degree), steepy and steepy slopes (20-45\% slope degree), infilled valley bottoms

Lithology: tertiary marls and sandy marls (unconsolidated) parcels were sampled by means of field work, laboratory analysis and spatial data analysis by means of geographic information system (GIS). Table 2 summarises the sampled factors and the method of measurement or determination.

The vector-raster GIS software ArcInfo was used for data acquisition and analysis. The contour lines defining the topography of the parcels and the nearby area and spot heights were digitised from large-scale topographic maps (1:5000 scale, $5 \mathrm{~m}$ contour interval) produced by the Cartographic Institute of Catalonia. From these contour lines a digital elevation model (DEM) was produced by means of spatial linear interpolation. The drainage lines were computed using a program developed by Martínez-Casasnovas and Stuiver (1998). This automatically reproduces the best fit stream network from a DEM as compared with the stream network drawn by aerial photo-interpretation or/and field observation.

The boundaries of the elementary sampling units were computed by applying the ArcGrid function watershed to the outlets of the main drainage line (Fig. 2).

Once the 23 terrain and land use/management variable data was collected, a statistical analysis of the individual factors was performed. The Student's $t$ test was applied to quantitatively measured factors and the chi-square test was applied to qualitative factors.

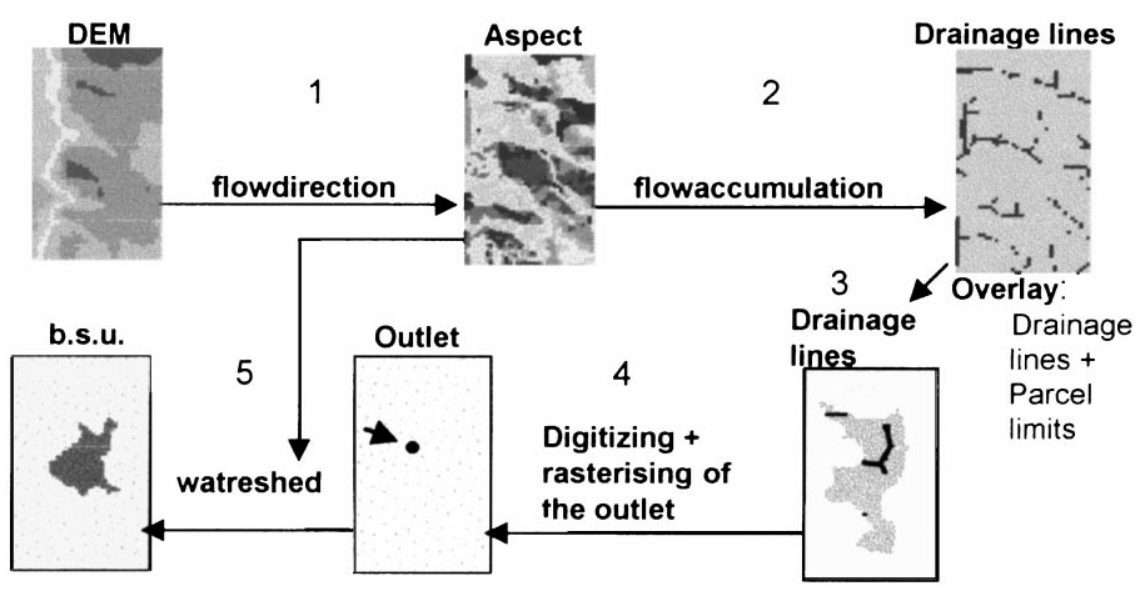

Fig. 2. Automatic delineation of the basic information unit (b.s.u.). 
Table 2

Relief, soil, and land use/management factors and sampling methods

\begin{tabular}{|c|c|c|}
\hline Factor & Definition & Method of measurement \\
\hline Relief position & $\begin{array}{l}\text { Position of the b.s.u. on the slope (from the } \\
\text { water divide to the foot of the slope) }\left({ }^{\circ}\right)\end{array}$ & Field observations \\
\hline Slope degree & $\begin{array}{l}\text { Mean of the slope degree of the different } \\
\text { slope segments of the b.s.u. }\end{array}$ & $\begin{array}{l}\text { In the field: measured with the clinometer on slope } \\
\text { segments not larger than } 30 \mathrm{~m} \\
\text { In laboratory: DEM analysis (function curvature, } \\
\text { ArcInfo-Grid }^{\mathrm{TM}} \text { ) }\end{array}$ \\
\hline Slope contour form & Planform curvature of the b.s.u. & $\begin{array}{l}\text { In the field: visual observation } \\
\text { In laboratory: DEM analysis (function curvature, } \\
\text { ArcInfo-Grid }^{\mathrm{TM}} \text { ) }\end{array}$ \\
\hline Slope profile form & Profile curvature of the b.s.u. & $\begin{array}{l}\text { In the field: visual observation } \\
\text { In laboratory: DEM analysis (function curvature, } \\
\text { ArcInfo-Grid }^{\mathrm{TM}} \text { ) }\end{array}$ \\
\hline Exposition & Direction of the maximum slope & $\begin{array}{l}\text { In the field: magnetic needle } \\
\text { In laboratory: DEM analysis (function curvature, } \\
\text { ArcInfo-Grid }^{\mathrm{TM}} \text { ) }\end{array}$ \\
\hline Area & Area of the b.s.u. $\left(\mathrm{m}^{2}\right)$ & In laboratory: calculation by means of GIS \\
\hline Length & Maximum length of the b.s.u. (m) & Field measurements \\
\hline Variance of the slope degree & Variance of the slope degree within the b.s.u. & $\begin{array}{l}\text { Automatic calculation by means of DEM analysis } \\
\text { in raster based GIS }\end{array}$ \\
\hline Relief amplitude & Maximum altitude difference within the b.s.u. & In laboratory: DEM analysis by means of GIS \\
\hline Distance outlet b.s.u.-large gully & $\begin{array}{l}\text { Distance between the outlet of the water flow } \\
\text { of the b.s.u. and the nearest large gully }(\mathrm{m})\end{array}$ & Measurement in field \\
\hline Type of vineyard plantation & Traditional/modern plantation & Field observations \\
\hline Vine rows pattern & $\begin{array}{l}\text { Orientation of the vine rows with respect to } \\
\text { the maxim slope }\end{array}$ & Field observations \\
\hline Conservation practices & Existence of conservation practices and type & Field observations \\
\hline Levelling measures & Existence or non-existence of levelling measures & $\begin{array}{l}\text { Determination in the field and consultation with the } \\
\text { owner of the farm }\end{array}$ \\
\hline Drainage channel & Existence drainage channels & Determination in the field \\
\hline Soil texture & Soil texture of the Ap horizon & $\begin{array}{l}\text { Laboratory analysis: sedimentation and sieve } \\
\text { analysis of the samples }\end{array}$ \\
\hline Soil structure & Structure of the Ap horizon & Determination in the field \\
\hline Organic matter content & Organic matter content of the Ap horizon (m) & Laboratory analysis: method: Walkley-Black \\
\hline Soil surface crusting & Existence of crusts on the soil surface & Field observations \\
\hline Soil depth & Soil depth up to a limiting layer & Field observations by drilling with an auger hole \\
\hline Soil class & & Soil Taxonomy (SSS, 1975, 1996) \\
\hline Stoniness of the soil surface & Cover of the soil surface by stones (\%) & Determination in the field by means of key legends \\
\hline Lithology & Type of parent material & $\begin{array}{l}\text { Determination in the field by means of drilling with } \\
\text { an auger hole }\end{array}$ \\
\hline
\end{tabular}

The objective of these tests was to determine the existence of significant differences between the data from parcels with observed gully erosion and from parcels without evidences of gully erosion.

The prediction of the existence of gully erosion at vineyard parcel level was based on a logistic regression of binary response (Press and Wilson, 1978; Hosmer and Lemeshow, 1989). The dependent variable is either the existence of gully erosion or the nonexistence of gully erosion. The model computes the probability that the affirmative statement occurs. Independent variables were the factors with a significant statistical relationship. In this respect, a multiple statistical analysis, stepwise regression, was performed to select the factors showing the highest relationship with gully erosion existence. The stepwise regression analysis performs an economic parameterisation since relationships among the variables are taken into account, avoiding a problem of multicollineasation (Bahrenberg et al., 1992). 
A logistic regression model of binary response (existence or non-existence of gully erosion) was computed using the selected variables. This model calculates the probability that the dependent variable takes the affirmative value. Quantitative as well as qualitative variables are possible in the equation. The statistical package $\mathrm{SAS}^{\mathrm{TM}}$ was used to perform the mentioned statistical analysis.

The empiric-stochastical model was implemented in the Image Calculator of Idrisi using a DEM of $25 \mathrm{~m}$ resolution. In this way, the probability of existence of gully erosion was computed in the entire study area. The $25 \mathrm{~m}$ resolution DEM was the most detailed available DEM for the entire study area. In this respect, the predictions based on the use of this DEM may produce default results.

The map of the probability of gully erosion existence was used to assess the predictions of the resulting gully erosion model. For this, 52 parcels different from the training data set that represent an area of $1.5 \%$ over the total study area were sampled. Two probability levels were considered as threshold of the existence or not of gully erosion: $<35 \%$ and $>65 \%$. If in reality gully erosion does not exist in a parcel the model must calculate a probability $<35 \%$ to be considered as being correctly assessed. For parcels with observed gully erosion, a probability $>65 \%$ is considered as being correctly assessed. Probabilities between $35 \%$ and $65 \%$ are not frequent since the proposed model is of a binary response type (existence or non-existence of gullies), and these predictions suppose commission errors.

\section{Results and discussion}

\subsection{Gully erosion determining factors in the Alt Penedès-Anoia region}

Tables 3 and 4 summarise the results of the statistical tests performed to determine the relationship between the considered terrain and land use/management factors and existing gully erosion.

The slope and the rate of the spatial variability of the slope degree are the quantitatively measured factors that show a highest relationship with the existence of gully erosion at vineyard parcel level $(P<0.01)$. The high spatial variability of the slope degree is asso- ciated with complex slope forms that produce the concentration of runoff. This concentration of runoff, either in natural ways or drainage channels, favours the development of gullies.

Some soil characteristics and type of underlying materials also showed a relationship with the existence of gully erosion $(P<0.05)$. Parcels with gullies showed a higher clay content, a lower organic matter, and lower sand or surface stoniness percentages than parcels without evidences of gully erosion.

The results indicate that topographic factors and management practices that favour the concentration of runoff can be pointed as the main factors associated with the existence of gully erosion in the study area. The improvement of soil characteristics such as organic matter content or the establishment of a mulch can reduce the risk of gully erosion, but more effective results would be achieved by designing appropriate drainage channel networks avoiding an excessive runoff concentration.

\subsection{Prediction of existing gully erosion}

\subsubsection{Selection of variables (stepwise regression)}

The stepwise regression analysis determined the variables slope steepness and planform curvature as the highest related to the existence of gullies in vineyard parcels (Table 5).

This indicates that the formation of gullies is mainly determined by topographic factors. Most of the parcels with observed gullies have a concave contour form. On the other hand, in $35 \%$ of the parcels without gullies the water flows upon a convex slope form and a rectilinear slope form in $45 \%$ of the cases.

These results agree with the findings of Richter (1965) and De Oliveira (1990), who found that the majority of the gullies appear in concave slope forms, and thus the risk of gully erosion increases in these slope forms during intense rainfalls.

The slope degrees of the parcels with gully erosion are higher than those without gullies. There is wider evidence in the literature suggesting that the slope degree has a great significance in erosion processes. It includes not only sheet erosion but also linear erosion such as rill or gully forms. A higher slope degree increases the velocity of the runoff that causes huge soil losses (Marks et al., 1992). López Bermúdez and 
Table 3

Results of the $t$-test

\begin{tabular}{|c|c|c|c|c|c|c|c|c|c|c|c|}
\hline & $\begin{array}{l}\text { Slope } \\
\left({ }^{\circ}\right)\end{array}$ & $\begin{array}{l}\text { Length } \\
\text { (m) }\end{array}$ & $\begin{array}{l}\text { Slope } \\
\text { degree } \\
\text { variance }\end{array}$ & $\begin{array}{l}\text { Area } \\
\left(\mathrm{m}^{2}\right)\end{array}$ & $\begin{array}{l}\text { Sand } \\
(\%)\end{array}$ & $\begin{array}{l}\text { V. fine } \\
\text { sand+silt } \\
(\%)\end{array}$ & $\begin{array}{l}\text { Clay } \\
(\%)\end{array}$ & $\begin{array}{l}\text { Organic } \\
\text { matter } \\
(\%)\end{array}$ & $\begin{array}{l}\text { Surface } \\
\text { stoniness } \\
(\%)\end{array}$ & $\begin{array}{l}\text { Stoniness } \\
\text { Ap } \\
(\%)\end{array}$ & $\begin{array}{l}\text { Soil } \\
\text { depth } \\
(\mathrm{cm})\end{array}$ \\
\hline $\mathrm{x}$ ero & 5.25 & 121.4 & 1.98 & 15569.1 & 28.95 & 48.12 & 22.93 & 1.46 & 4.45 & 12.17 & 65.35 \\
\hline $\mathrm{x}$ nero & 2.96 & 144.6 & 1.46 & 148631 & 35.16 & 46.09 & 18.34 & 1.74 & 8.40 & 14.73 & 68.50 \\
\hline $\begin{array}{l}t \text {-test } \\
t \text {-tab }\end{array}$ & 6.27 & 0.99 & 2.54 & 0.12 & 1.73 & 0.80 & 2.16 & 1.98 & 1.98 & 1.15 & 0.53 \\
\hline$P=0.05$ & 1.68 & 1.68 & 1.73 & 1.68 & 1.68 & 1.68 & 1.68 & 1.68 & 1.73 & 1.73 & 1.68 \\
\hline \multirow[t]{2}{*}{$P=0.01$} & 2.42 & 2.42 & 2.54 & 2.42 & 2.42 & 2.42 & 2.42 & 2.42 & 2.54 & 2.54 & 2.42 \\
\hline & $P<0.01$ & & $P<0.01$ & & $P<0.05$ & & $P<0.05$ & $P<0.05$ & $P<0.05$ & & \\
\hline
\end{tabular}

$\mathrm{x}$ ero - mean of the b.s.u. with gully erosion; x nero - mean of the b.s.u. without evidences of gully erosion; $t$-test - calculated value; $t$-tab - value of the $t$-table for the correspondent degrees of freedom.

Table 4

Results of the chi-square test

\begin{tabular}{|c|c|c|c|c|c|c|c|c|c|c|}
\hline & $\begin{array}{l}\text { Relief } \\
\text { position }\end{array}$ & $\begin{array}{l}\text { Planform } \\
\text { curvature }\end{array}$ & $\begin{array}{l}\text { Profile } \\
\text { curvature }\end{array}$ & Exposition & $\begin{array}{l}\text { Surface water } \\
\text { concentration }\end{array}$ & $\begin{array}{l}\text { Vine rows } \\
\text { pattern }\end{array}$ & $\begin{array}{l}\text { Drainage } \\
\text { channel }\end{array}$ & $\begin{array}{l}\text { Levelling } \\
\text { measures }\end{array}$ & Structure & Lithology \\
\hline \multirow{3}{*}{$\begin{array}{l}\chi^{2} \text {-test } \\
\chi^{2} \text {-tab } \\
P=0.05 \\
P=0.01\end{array}$} & 6.09 & 12.16 & 7.83 & 0.50 & 24.12 & 3.75 & 8.56 & 16.5 & 4.45 & 6.23 \\
\hline & 9.49 & $\begin{array}{l}5.99 \\
9.21\end{array}$ & 5.99 & 3.84 & $\begin{array}{l}3.84 \\
6.63\end{array}$ & 7.81 & $\begin{array}{l}3.84 \\
6.63\end{array}$ & $\begin{array}{l}3.84 \\
6.63\end{array}$ & 7.81 & 5.99 \\
\hline & & $P<0.01$ & $P<0.05$ & & $P<0.01$ & & $P<0.01$ & $P<0.01$ & & $P<0.05$ \\
\hline
\end{tabular}

$\chi^{2}$-test - calculated value; $\chi^{2}$-tab - value of the chi-square table for the correspondent degrees of freedom. 
Table 5

Results of the stepwise regression

\begin{tabular}{|c|c|c|c|c|c|c|c|}
\hline \multirow[t]{2}{*}{ Step } & \multicolumn{2}{|l|}{ Variable } & \multirow[t]{2}{*}{ Number in } & \multirow[t]{2}{*}{ Score chi-square } & \multirow[t]{2}{*}{ Wald chi-square } & \multirow[t]{2}{*}{$\operatorname{Pr}>$ chi-square } & \\
\hline & Entered & Removed & & & & & \\
\hline \multicolumn{8}{|c|}{ Summary of stepwise procedure } \\
\hline 1 & SLOPE & & 1 & 8.1545 & - & 0.0043 & \\
\hline 2 & $\mathrm{ZX}$ & & 2 & 5.1106 & - & 0.0238 & \\
\hline 3 & $\mathrm{ZCX}$ & & 3 & 0.2853 & - & 0.0384 & \\
\hline 4 & & $\mathrm{ZCX}$ & 2 & - & 3.6635 & 0.0556 & \\
\hline Variable & $\mathrm{DF}$ & $\begin{array}{l}\text { Parameter } \\
\text { estimates }\end{array}$ & $\begin{array}{l}\text { Standard } \\
\text { error }\end{array}$ & $\begin{array}{l}\text { Wald } \\
\text { chi-square }\end{array}$ & $\begin{array}{l}\operatorname{Pr}> \\
\text { chi-square }\end{array}$ & $\begin{array}{l}\text { Standardised } \\
\text { estimate }\end{array}$ & $\begin{array}{l}\text { Odds } \\
\text { ratio }\end{array}$ \\
\hline \multicolumn{8}{|c|}{ Analysis of maximum likelihood estimates } \\
\hline INTERCPT & 1 & -3.2150 & 1.3296 & 5.8469 & 0.0156 & - & - \\
\hline $\mathrm{ZX}$ & 1 & -3.0642 & 1.5173 & 4.0783 & 0.0434 & -0.631298 & 0.047 \\
\hline SLOPE & 1 & 1.0197 & 0.3660 & 7.7635 & 0.0053 & 1.058461 & 2.772 \\
\hline \multicolumn{8}{|c|}{ Association of predicted probabilities and observed responses } \\
\hline Concordant & $85.0 \%$ & Somers'D & 0.782 & & & & \\
\hline Discordant & $15.0 \%$ & Gamma & 0.700 & & & & \\
\hline \multirow[t]{2}{*}{ Tied (340 pairs) } & $0.0 \%$ & Tau-a & 0.357 & & & & \\
\hline & & $c$ & 0.850 & & & & \\
\hline
\end{tabular}

Albadalejo, 1990 go a step further in their interpretation because they infer that a high slope degree is responsible for an increase of runoff and for a tendency to flow concentration. Meyer et al. (1975) found that erosion caused by concentrated water flow existence of a rectilinear planform curvature, and $X$ is the existence of a convex planform curvature.

The log-transformation of Eq. (1) gives Eq. (2), from which the probability $p$ can be computed.

Eq. (2): Logistic model

$$
p=\frac{\exp (-1.8744+0.8246 * \mathrm{SLOPE}-3.2843 * X-2.0361 * R)}{1+\exp (-1.8744+0.8246 * \mathrm{SLOPE}-3.2843 * X-2.0361 * R)}
$$

increases about 20 times between a slope degree of $2 \%$ and $20 \%$.

\subsubsection{The logistic model}

The application of the logistic regression analysis of binary response, with slope steepness and planform curvature as independent variables, produced an equation that computes the probability gullies found within vineyard parcels (Eq. (1)).

Eq. (1): Log-linear model

$$
\begin{aligned}
\lg (p)= & -1.8744+0.8246 * \text { SLOPE }-3.2843 * X \\
& -2.0361 * R,
\end{aligned}
$$

where $p$ is the probability of existence of gully erosion, SLOPE the value of slope degree (degrees), $R$ the
The probability can take values between 0 and 1 , although for this discussion percentage values are used.

In the case the planform curvature is concave, the convex form $X$ and the rectilinear form $R$ are set to 0 . The probability therefore is only determined by the slope steepness. In the case the planform curvature is convex, the variable $R$ is set to 0 and the variable $X$ is set to 1 . The opposite happens when a rectilinear slope exists: variable $X$ is set to 0 and the variable $R$ is set to 1 .

If the regression coefficient that accompanies a variable takes a positive value, it means the variable which contributes to increase the probability gullies are found in a parcel. This is true in the case of the 
variable slope steepness with its positive partial regression coefficient of 0.8246 . Negative coefficients -3.2843 and -2.0361 , respectively, accompany the variables $X$ and $R$. Because of that, they $(X$ and $R$ ) are regarded as variables that reduce the risk of gully erosion. In the case of a concave slope the probability of gully erosion existence depends on the slope degree. A concave slope is therefore considered as a factor directly responsible for gully erosion.

The model was statistically assessed by the Somers'D-coefficient, which yielded a value of 0.782 , and the goodness-of-fit test that produced a value of 0.8424 . This means the model fits the reference data (84.24\% of the reference cases are predicted by the model) (Hosmer and Lemeshow, 1989). A better adjustment can be achieved by eliminating ill-fitted observations, which substantially contribute to a disagreement between the training data and the predicted values. Ill-fitted observations may correspond with parcels that present gully erosion caused by other factors different from the ones considered by the model, such as seepage produced by near saturated soil conditions out of the natural drainage channels, or concentration of runoff by farmers at specific points in the parcel. In the present case, only one observation was considered as ill-fitted and it was rejected (Fig. 3).

\subsubsection{Interval of confidence of the model}

The existence of gullies in vineyard parcels can be analysed with respect to the variation of the independent variables in Eq. (2). The probability increases with slope steepness and from convex to concave slope forms. Table 6 shows an analysis of threshold slope degrees for different slope planar forms and different probabilities.

Vineyard parcels with convex contour form should have a slope degree of at least $11.82^{\circ}$ to have $99 \%$ probability of development of gullies. In rectilinear

\section{Delta Chisquare}

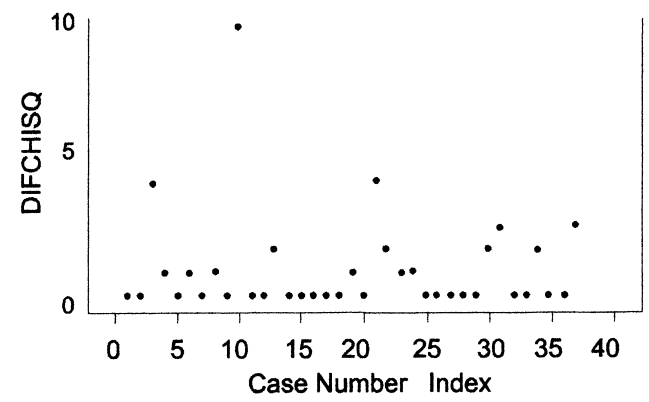

Delta Deviance

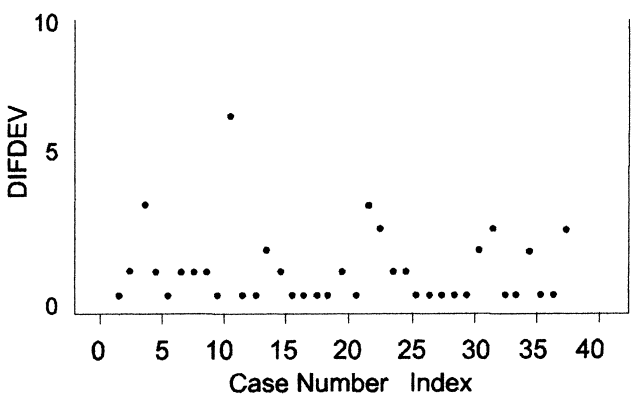

Fig. 3. The results of the DIFCHISQU and DIFDEV regression diagnostics (observation number 10 was rejected because of the high delta chi-square and deviation differences).

slopes, a degree of $10.31^{\circ}$ represents the threshold value for the same probability level, and in the case of concave slopes, this threshold value is $7.85^{\circ}$. For lower probability levels, the same pattern exists (Fig. 4).

In general, logistic modelling may produce erroneous assessments when the independent values reach extreme values. In the present case, for slope degrees exceeding $31^{\circ}$, the probability comes up to $100 \%$, no matter what type of curvature contour form is concerned. Inaccuracies begin at a slope degree of $15^{\circ}$. In our study area, this should not be considered as a

Table 6

Threshold slope degrees for different slope planar forms and probability levels

\begin{tabular}{llll}
\hline $\begin{array}{l}\text { Probability } \\
(\%)\end{array}$ & $\begin{array}{l}\text { Slope degree at } \\
\text { convex slope forms }\left({ }^{\circ}\right)\end{array}$ & $\begin{array}{l}\text { Slope degree at } \\
\text { rectilinear slope forms }\left(^{\circ}\right)\end{array}$ & $\begin{array}{l}\text { Slope degree at c } \\
\text { oncave slope forms }\left({ }^{\circ}\right)\end{array}$ \\
\hline 99 & 11.82 & 10.31 & 7.85 \\
65 & 7.81 & 7.41 & 4.94 \\
35 & 5.51 & 5.49 & 3.02 \\
10 & 3.59 & 2.08 & - \\
\hline
\end{tabular}




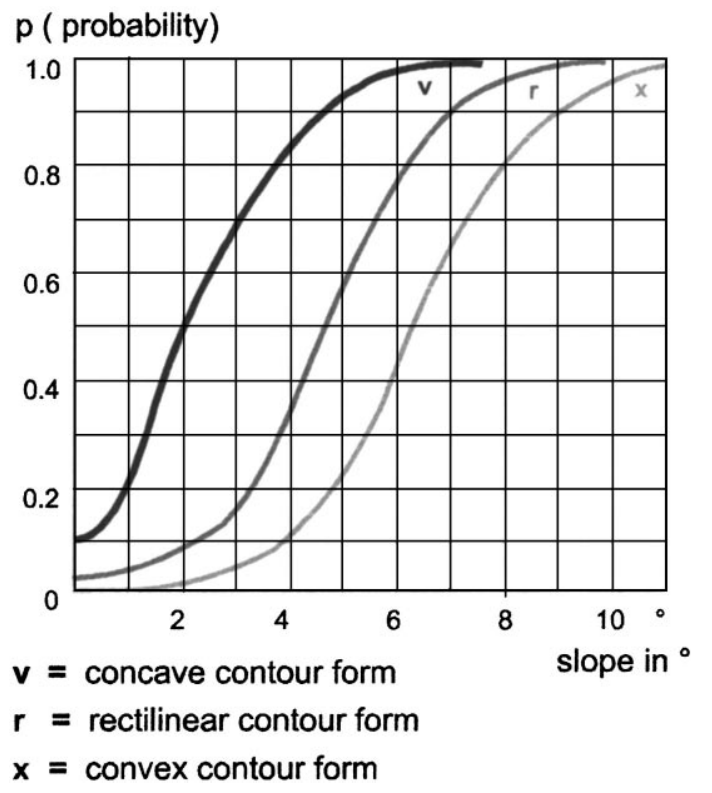

Fig. 4. Logistic curves for each slope contour form.

problem since vineyards or other areas under cultivation only seldom occur at slopes above $15^{\circ}$. More attention must be paid when low slope degree values are considered. Slope degrees close to $0^{\circ}$ produce probability values greater than $10 \%$ for parcels with concave contour forms. For other slope contour forms this problem can be ignored, but for concave contour forms the threshold slope degree below which an erroneous assessment can be made is about $1^{\circ}$.

\subsubsection{Application and validation of the model}

The logistic regression model (Eq. (2)) was applied to the Rierussa and Romani-Bribons catchment areas. For the spatial depiction of probability of the existing gully erosion in those areas, a raster slope degree map and a raster planar contour map of $25 \mathrm{~m}$ resolution were used. Fig. 5 shows the output probability map.

Parcels in the Rierussa catchment have a higher probability of existence of gully erosion. The existence of gullies is possible nearly everywhere. This is due to a relief with dominance of complex slopes and relative high slope degrees for agricultural uses without erosion control measures. On the other hand, in the Romani-Bribons catchment, only some areas show a high probability value. These are mainly located in the steep slopes associated to the residual planation surfaces of the adjacent piedmont landscape unit. The dissection of these landforms is controlled by tertiary conglomerats. However, there are parts of the slope where calcilutites outcrop have a higher potential risk. Other large areas with low probability of gully existence are found in the Romani-Bribons catchment, as for example the alluvial areas of the Riera Bribons. Here, protective measures are not so essential as for the Rierussa catchment.

To assess the validity of the predictions made by the model, an error matrix was produced by comparison of reference data and predicted data (Table 7). The overall accuracy of the model is $84.6 \%$. The high overall error of commission $(39.5 \%)$ is mainly produced by parcels with probability values between $35 \%$ and $65 \%$, which have not been classified in any of the established reference data categories. Probabilities between $35 \%$ and $65 \%$ are not usual, since the model tends to predict values close to $0 \%$ or $100 \%$ (nonexistence or existence of gully erosion), and therefore are overvaluing the error. On the other hand, the overall error of omission can be considered as low $(15.3 \%)$. In this case study, it mainly indicates parcels without gully erosion but with predicted gully erosion

Table 7

Error matrix for the assessment of the existing gully erosion prediction in the Alt Penedès-Anoia region

\begin{tabular}{lllllc}
\hline Reference data & Predicted data & & & \\
\cline { 2 - 6 } & $\begin{array}{l}\text { Gully erosion } \\
p>65 \%\end{array}$ & $\begin{array}{l}\text { Not determined } \\
35 \%>p>65 \%\end{array}$ & $\begin{array}{l}\text { No gully erosion } \\
p<35 \%\end{array}$ & $\begin{array}{l}\text { Total } \\
\text { Errors of } \\
\text { omission }(\%)\end{array}$ \\
\hline Gully erosion & 26 & 0 & 0 & 26 & 0 \\
No gully erosion & 6 & 2 & 18 & 26 & 30.7 \\
Total & 32 & 2 & 18 & 52 \\
Errors of commission $(\%)$ & 18.7 & 100 & 0 & & \\
\hline
\end{tabular}

Overall accuracy $=84.6 \%$. Overall error of commission $=39.5 \%$. Overall error of omission $=15.3 \%$. 
The Riera Romani-Bribons catchment

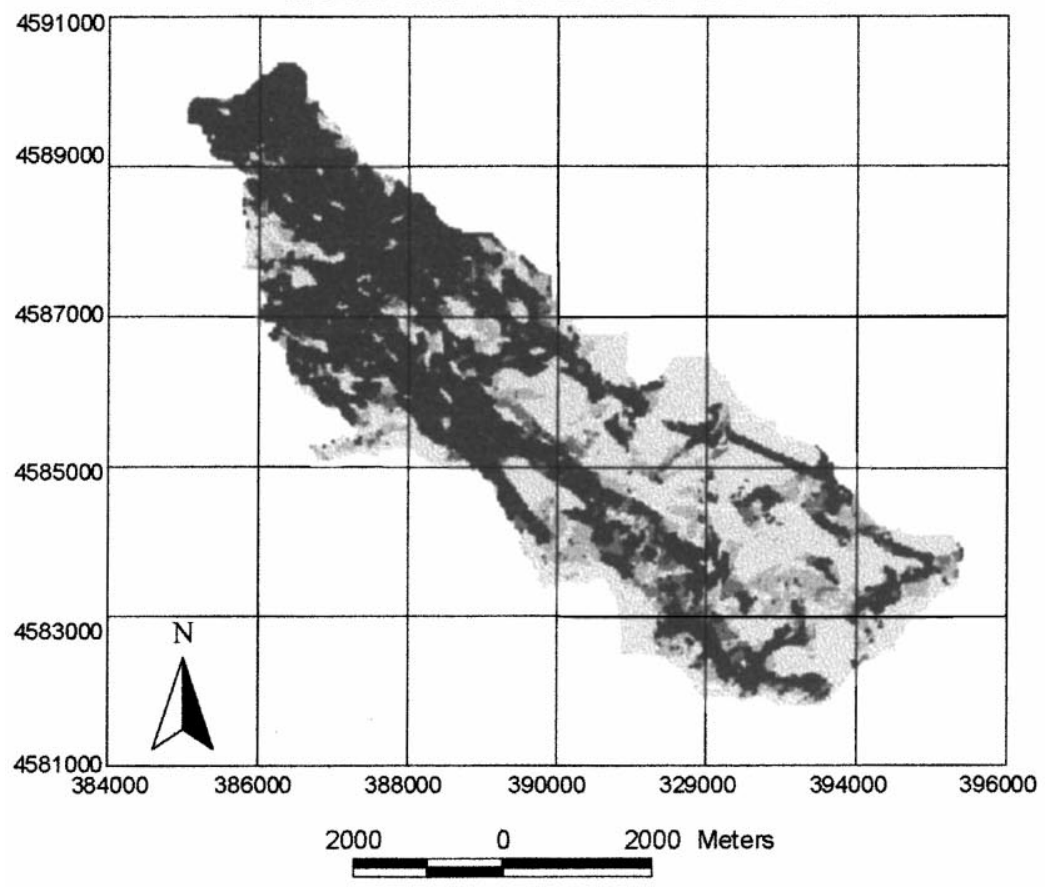

\section{Legend}

Probability in \% of the development of gullies

$$
\begin{aligned}
& \square \quad 0-25 \% \quad \square>50-75 \% \\
& \square>25-50 \% \quad \square>75-100 \%
\end{aligned}
$$

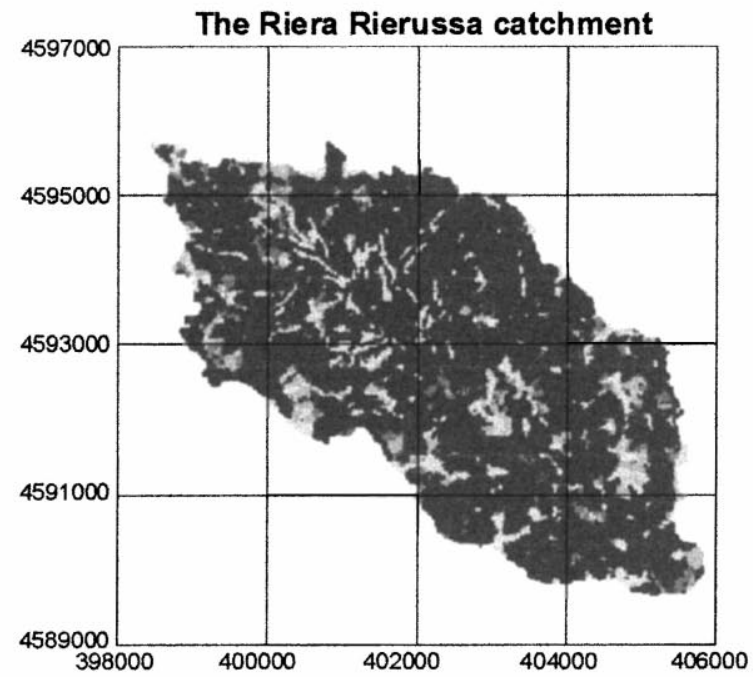

Fig. 5. Probability of existence of gully erosion at vineyard parcels in the Rierussa and Romani-Bribons catchments (Alt Penedès-Anoia region). 
in the map. It should be considered as a permissive error since it is saying that some parcels require control measures when in reality the risk of gully erosion is low. A positive point of the predictive gully erosion model is that no errors of omission were found, which implies that existing gully erosion is always predicted correctly.

The use of a lower resolution DEM for the application of the model to the entire study area than that used for data acquisition may produce default results. Complex micro-relief, that may led to concentration of runoff and development of gullies in some cases, is not reflected in the lower resolution DEM. In this case, the application of the model would give erroneous predictions. Nevertheless, the use of the still detailed $25 \mathrm{~m}$ resolution DEM can be considered as useful in areas where a more generalised view of the existing probable gully erosion is needed for prioritisation of control planning at catchment level.

\section{Conclusions}

This paper presents a study of determining factors concerning gully erosion and a methodological approach to model the probability of gully erosion existence in vineyard parcels using reference data from the Alt Penedès-Anoia region (NE Spain).

The modelling of the existence of gully erosion in terms of probability can better support decision making on implementing preventive and control measures in intensive agricultural areas, where continuous tilling can mask the existence of gullies.

The proposed model is an empiric-stochastical type. For other study areas, the methodological approach based on logistic regression is applicable. In this respect, the model increases its usefulness when the independent variables can be modelled by means of geographical information systems (GISs), which allows the automation of the application.

Regarding the results of the application of the model in the study area, under similar lithologic characteristics, topographical and management practices associated with water flow concentration showed the highest relationship with the existence of gully erosion at parcel level. More complex slopes and the higher slope degrees resulted in a higher probability of finding gullies in vineyard parcels. In this respect, the ranking of the probability of existence of gully erosion can be useful in the prioritisation of soil conservation planning at catchment level.

\section{References}

Bahrenberg, G., Giese, E., Nipper, J., 1992. Statistische Methoden in der Geographie. Multivariate Statistik, vol. 2. Teubner Studienbücher Geographie, Stuttgart.

Crouch, R.J., Blong, R.J., 1989. Gully sidewall classification: methods and applications. Z. Geomorph. N.F. 33(3), 291-305.

De Oliveira, M.A.T., 1990. Slope geometry and gully erosion development: Bananal, São Paulo, Brazil. Z. Geomorph. N.F. 34(4), 423-434.

Donker, N.H.W., Damen, M.C.J., 1984. Gully system development and assessment of gully initiation risk in Miocene deposits near Daroca - Spain. Z. Geomorph. N.F., Suppl. Bd. 49, 37-50.

Heede, H., 1970. Morphology of gullies in the Colorado Rocky mountains. Bull. Int. Ass. Sci. Hydrology 15, 42-50.

Heede, H., 1979. Gully development and control. USDA Forest Service Research Paper RM-169, 2nd ed. Fort Collings.

Hill, J., 1993. Monitoring land degradation and soil erosion in Mediterranean environments. ITC J. 4, 323-331.

Hosmer, D.W., Lemeshow, S., 1989. Applied Logistic Regression. Wiley, New York.

Imeson, A.C., Kwaad, F.J.P.M., 1980. Gully types and gully prediction. K.N.A.G. Geogr. Tjds. XVI 5, 430-441.

Ireland, H.A., Sharpe, C.F., Eargle, D.H., 1939. Principles of gully erosion in the Piedmont of South Carolina. US Department of Agriculture Technological Bulletin 63.

Laflen, J.M., Watson, D.A., Franti, T.G., 1986. Ephemeral gully erosion. Proceedings of the Fourth Federal Interagency Sedimentation Conference, Las Vegas, 23-27 March, pp. 3.29-3.37.

López Bermúdez, F., Albadalejo, J., 1990. Factores ambientales de la degradación del suelo en el área mediterránea. In: Albadalejo, J., Stocking, M.A., Díaz, E. (Eds.), Degradación y Regeneración del suelo en condiciones ambientales mediterráneas. Murcia, pp. 15-45.

Marks, R., Müller, J.M., Leser, H., Klink, H.J., 1992. Anleitung zur Bewertung des Leistungsvermögens des Landschaftshaushaltes. Forschungen zur deutschen Landeskunde, vol. 229. Selbstverlag, Trier.

Martínez-Casasnovas, J.A., 1998. Suelos-Paisaje-Erosión. Erosión por cárcavas y barrancos en el Alt Penedès-Anoia (Cataluña). Un enfoque de estudio mediante tecnologías de la información espacial: Bases de datos, Sistemas de Información Geográfica (SIG) y Teledetección. Ph.D. Thesis (unpublished), University of Lleida, Lleida.

Martínez-Casasnovas, J.A., Stuiver, J., 1998. Automatic delineation of drainage networks and elementary catchments from digital elevation models, ITC J. 3(4), 198-208.

Meyer, L.D., Foster, G.R., Romkens, M.J.M., 1975. Source of soil eroded by water from upland slopes. US Dep. Agr. Agric. Res. Serv. (ARS-S-40). 
Poesen, J., 1989. Conditions for gully formation in the Belgian loam belt and some ways to control them. Soil Technol. Ser. 1, $39-52$.

Poesen, J., Govers, G., 1990. Gully erosion in the loam belt of Belgium: typology and control measures. In: Boardman, J., Foster, I.D.L., Dearing, J.A. (Eds.), Soil Erosion on Agricultural Land. Wiley, New York, pp. 513-530.

Porta, J., Ramos, M.C., Boixadera, J., 1994. Mechanical measures for runoff management and erosion control in the vineyards of North East Spain. In: Rickson, R.J. (Ed.), Conserving Soil Resources: European Perspective. CAB International, Wallingford, pp. 369-378.

Press, S.J., Wilson, S., 1978. Choosing between logistic regression and discriminant analysis. J. Am. Stat. Assoc. 73, 699705.

Ramos, M.C., Porta, J., 1993. Modelos de distribución espaciotemporal de las lluvias en la zona Mediterránea del AnoiaPenedès. Influencia en la sostenibilidad de los cultivos de la zona. Ecología 7, 47-56.

Ramos, M.C., Porta, J., 1994. Rainfall intensity and erosive potenciality in the NE Spain Mediterranean area. Il Nuovo Cimento 17C(3), 291-299.

Richter, G., 1965. Bodenerosion, Schäden und gefährdete Gebiete in der Bundesrepublik Deutschland. Gutachten vorgelegt vom Inst. f. Landekde, Selbstverlag d. Banst. f. Landeskde und Raumforschg, Bad Godesberg.

Rieger, W., 1993. Hydrological terrain features derived from a pyramid raster structure. In: Kovar, K., Natchtnebel, H.P. (Eds.), Application of Geographical Information Systems in
Hydrology and Water Resources Management, vol. 211. IAHS Publication, Oxfordshire, pp. 201-210.

Seginer, I., 1966. Gully development and sediment yield. J. Hydrol. 4, 236-253.

SSS, 1975. Soil Taxonomy: A basic system of soil classification for making and interpreting soil surveys. Agric. Handbook 436. US Govt. Printing Office, Washington, DC, USA.

SSS, 1996. Keys to Soil Taxonomy, 7th ed. US Department of Agriculture - Natural Resources Conservation Service, Washington, DC, 1996

Stocking, M.A., 1980. Examination of the factors controlling gully growth. In: De Boodt, M., Gabriels, D. (Eds.), Assessment of Erosion. Wiley, Chichester, UK, pp. 505-520.

Thompson, J.R., 1964. Quantitative effect of watershed variables on rate of gully head advancement. Trans. Am. Soc. Agric. Eng. 7, 54-55.

Uson, A., 1998. Medidas de control de erosión en suelos de viña de las comarcas Anoia-Alt Penedès (Barcelona): efectividad y viabilidad. Ph.D. Thesis, Universitat de Lleida, Lleida.

Vandaele, K., Poesen, J., Govers, G., Van Wesemael, B., 1996. Geomorphic threshold conditions for ephemeral gully incision. Geomorphology 16, 161-173.

Williams, A.R., Morgan, R.P.C., 1976. Geomorphological mapping applied to erosion evaluation. J. Soil Water Conser. 31(4), 164 168.

Zink, A., 1997. Riesgos ambientales y suelos. Enfoques para la modelización de la erosión por cárcavas y movimentos en masa. Edafología, Special Edition of the 50th Anniversary of the Spanish Soil Science Society, pp. 283-297. 